майстерності в процесі навчання грі на баяні / О. Паньков. - Кривий Ріг, 1995. - 376 с. 7. ЦДАЖР, ф. 166, оп. 2, с. 1568, л. 55. 8. ЦДАЖР, ф. 166, оп. 4, с. 613, л. 82-84. 9. ЦДАЖР, ф. 166, оп. 5, с. 1888, л. 4. 10. ЦДАЖР, ф. 318, оп. 1, с. 1394, л. 151. 11. ЦДАЖР, ф. 5116, оп. 12, с. 50, л. 4. 12. Архів Дніпропетровської області, ф. 4359 , оп. 1 , с. 137 , л. 37.

УДК 37(09)+1(09)

I. I. Гаврищак,

кандидат пед. наук, доцент,

Кременеиький обласний гуманітарно-педагогічний інститут ім. Тараса Шевченка

\title{
ПЕДАГОГІЧНІ АСПЕКТИ В НАУКОВІЙ ДІЯЛЬНОСТІ ІММАНУЇЛА КАНТА
}

Статтю присвячено дослідженню педагогічної діяльності відомого німеиького філософа I. Канта, особливу увагу приділено трактату «Про педагогіку», виокремлено концептуальні засади педагогічних положень твору, здійснено аналіз викладаиьккої діяльності німецького філософа.

Ключові слова: Іммануїл Кант, Кенігсберзький університет, педагогічна діяльність, педагогічна антропологія, виховання особистості.

Статья посвящена исследованию педагогической деятельности известного немеикого философа И. Канта, особенное внимание уделено трактату «О педагогике», выделены концептуальные идеи педагогических положений произведения, выполнен анализ преподавательской деятельности немеикого философа.

Ключевые слова: Иммануил Кант, Кенигсбергский университет, педагогическая деятельность, педагогическая антропология, воспитание личности.

The article investigates pedagogical activity of a famous German philosopher I. Kant, special attention is paid to the treatise "On Pedagogy». The conceptual provisions of the pedagogical foundations of the work were singled out; the analysis of teaching of the German philosopher was made.

Key words: Immanuel Kant, the University of Knigsberg, pedagogical activity, pedagogical anthropology, education of the individual.

Іммануїл Кант (1724-1804) давно посідає одне з чільних місць в історії європейської та світової культури. Доробок філософа був і донині продовжує залишатися в центрі уваги вітчизняних і зарубіжних науковців: проблемі людини у творчості І. Канта присвячено дослідження В. Асмуса, Б. БімБада, В. Бразаускі, М. Гайдегера, А. Гулиги, П. Гуревича, М. Деспленда, Ф. Каульбаха, П. Козловські, Г. Крутікової, М. Мамардашвілі, Г. Новічкової, Т. Ойзермана, Л. Чухіної та ін.; релігійні аспекти філософії вивчали Е. Биховський, Ф. Копллстон, С. Луговий, Л. Мітрохін, I. Нарський, Т. Ойзерман; історико-філософські та естетичні аспекти 
аналізували I. Бондаревська, I. Бичко, Ю. Кушаков, В. Шинкарук та ін.; освітні аспекти осмислювали Б. Бім-Бад, Н. Ничкало та інші.

Проте й нині науковці, досліджуючи науковий доробок I. Канта, здебільшого працюють в межах філософського дискурсу [3; 6; 7; 9; 10], визначених традицією ХХ ст. [4, с. 456, 467], залишаючи поза увагою той факт, що основною діяльністю Канта усе-таки була викладацька (десятки років він працював у Кенігсберзькому університеті, знаменитій «Альбертіні» - одному із найстаріших вищих навчальних закладів Пруссії, заснованому в 1544 р. герцогом Альбрехтом Гогенцоллерном - авт.). Окрім того, в центрі уваги опинилися здебільшого основні, класичні праці, є ще низка таких, які так і не знайшли поки що гідного поцінування і використання в педагогічній практиці. 3-поміж них - трактат I. Канта «Про педагогіку», який не тільки свідчить про конкретні зацікавлення філософа виховними проблемами, але в руслі утвердження ідей педагогічної антропології набуває нового якісного значення. Вітчизняна наука, як і російська педагогічна, має в цьому плані певні здобутки (наприклад, дисертаційні дослідження А. Буталової «Ідеї морального виховання в раціональній етиці I. Канта», I. Суслової «Етикопедагогічні погляди Іммануїла Канта в світлі сучасних проблем гуманізації освіти»). Завдяки активній діяльності академіка Б. Бім-Бада зараз спостерігаємо пожвавлення інтересу до педагогічних ідей І. Канта; в Україні за необхідність актуалізації творчої спадщини І. Канта висловлюється дійсний член НАН Н. Ничкало. Усе це обумовлює нагальну потребу переосмислення наукового доробку I. Канта з огляду на реальну можливість і потребу уведення його в педагогічний дискурс.

Mema cmammi - висвітлити педагогічні аспекти освітньої діяльності Іммануїла Канта.

Хрестоматійною стала інформація про те, що життя I. Канта $є$ бідним на зовнішні події. Він неохоче мандрував і навіть відмовився від високооплачуваної посади професора Берлінського університету, не бажаючи покидати Кенігсберг i змінювати звичний для нього ритм життя. Проте в цьому випадку йдеться про певні кількісні характеристики, тоді як треба брати до уваги якісні: будучи перш за все філософомпрактиком, Кант майже 50 років свого життя присвятив педагогічній діяльності. 
Восени 1740 р. І. Кант став студентом Кенігсберзького університету. Саме тут він познайомився з викладачем, якого тепер називають головним вчителем Канта, - професором Мартіном Кнутценом, що помер молодим - у віці 37 років. Цілком ймовірно, що саме під його впливом юнак почав працювати над роботою 3 фізики - «Думки про істинну оцінку живих сил». Писав іiі 3 роки, а друкував цілих 4 (упродовж 1746-1750 pp.).

У стінах університету Кант провів майже 7 років, залишивши його у 1747 р., так і не захистивши магістерської роботи, що означало тоді незавершену вищу освіту. На думку біографів, це стало результатом серйозних фінансових проблем.

Починається важливий період у його біографії, який врешті-решт приведе I. Канта до університетської кафедри: він працює приватним учителем у сім'ях представників різних соціальних верств. Спочатку Кант опиняється у Східній Пруссії у родині пастора Андерша (с. Юдшен, неподалік від м. Гумбіцена), через 3 роки працює у поміщика Гюльзена, а потім його запрошує на роботу граф Кайзерлінг. Ці роки не пропали марно не тільки щодо набуття практичного педагогічного досвіду, оскільки в цей час тривала напружена робота думки: був завершений рукопис «Космогонії, або Спроби пояснити походження всесвіту, утворення небесних тіл і причини їx руху загальними законами руху матерії відповідно до теорії Ньютона».

У цей час Кант серйозно задумується над перспективою викладацької роботи, тому готує і подає до захисту магістерську роботу «Про вогонь». Захист, що відбувся у формі прилюдного диспуту, був успішним, і Кант, нарешті, здобув повну університетську освіту. Проте для того, щоб мати право читати лекції, треба було підготувати ще одну дисертацію, захист якої мав бути публічним. У результаті Канту було присвоєно звання приват-доцента, тобто позаштатного викладача, робота якого оплачувалася самими студентами. Незабаром новий приват-доцент прочитав першу свою лекцію у залі, що знаходився у будинку професора Кіпке. «Слухачів зібралося більше, ніж міг умістити зал; студенти стояли на сходах і в передпокої. Кант спочатку розгубився, першу годину говорив зовсім нечітко, тільки після перерви оволодів собою» [2, с. 32]. Так розпочалася його викладацька робота, яка тривала майже 42 роки. 
Упродовж своєї праці в університеті Кант прочитав загалом 268 лекційних курсів, зокрема: теологія - 1, мінералогія - 1, механіка - 2, педагогіка - 4, енциклопедія філософських наук -11 , право - 12, математика -16 , теоретична фізика -20 , антропологія - 24, етика -28 , фізична географія - 46, метафізика - 49, логіка - 54 [2, с. 247].

Окремі лекційні курси Кант читав на основі підручників: логіку - за Майєром, метафізику - за Баумгартеном, педагогіку - за Базедовим і Бокком. Останній лекційний курс нині є, безперечно, особливо цікавим, оскільки матеріали не просто збереглися, а ще за життя філософа вийшли окремою книгою. Редактором видання «Кант про педагогіку» був учень, а згодом його колега Т. Рінк. Саме 3 його слів довідуємося, що такі курси в Кенігсберзькому університеті професори філософії читали для студентів по черзі. Сам Кант прочитав його вперше зимового семестра 1776-1777 pp., (у місцевій газеті було опубліковане оголошення такого змісту: «Практичні вказівки стосовно виховання; читає пан проф. Кант; публічно»), а потім ще тричі (востаннє - у 17861787 н. p.) [1].

Сам текст не просто засвідчує напружену роботу думки мислителя, але і дає змогу виокремити основопложні ідеї, які згодом будуть розвинуті ним у спеціальних філософських працях. Якщо ми спробуємо зіставити це із творчою біографією філософа, то можемо погодитися із твердженням, що трактат «Про педагогіку» тісно пов'язаний з такими творами, як «Критика чистого розуму» (1781), «Критика практичного розуму» (1788), «Метафізика нравів» (1797), навіть зумовив теоретичні пошуки у педагогічній царині.

Проаналізуємо основні положення педагогічних поглядів мислителя. Сприйнявши основну ідею Просвітництва про перетворення світу і вдосконалення людини за допомогою виховання й освіти, Кант органічно поєднав ії з ідеєю «бути людиною», проголосивши людину основною цінністю, зауважує Г. Новічкова: «Ідеєю людини пройнята вся творчість Канта, і жодна із сфер людської діяльності не залишилася поза його аналізом. Філософія Канта - якісно нова філософія, яка розглядає людину в усіх іiі виявах: як людину, що пізнає, моральну, що досягає досконалості завдяки вихованню» [8].

3 іменем Канта пов'язана поява такої науки, як філософська антропологія, що досліджує людину, прагнучи зібрати воєдино, синтезувати всі знання про неї, які дають різні 
світоглядні системи - наукові, релігійні тощо. Робота здійснюється 3 однією метою: відповісти на запитання, що таке людина?

«Усі успіхи, які є школою для людини, мають за мету застосовувати до життя набуті знання і вміння. Проте найголовніший предмет у світі, до якого ці пізнання можуть бути застосовані, - це людина. Тому що вона для себе своя остання мета. Відповідно, знання родових ознак людей як земних істот, обдарованих розумом, особливо заслуговує назви світознавство незважаючи на те, що людина лише частина земних створінь», - стверджує Кант у передмові до праці «Антропологія 3 прагматичної точки зору» (1798) [5, с. 351]. Думки, висловлені Кантом у трактаті «Про педагогіку», не просто $є$ суголосними висловленим у праці «Антропологія 3 прагматичної точки зору», вони явно випереджають останні в плані хронологічному і $є$ своєрідною фіксацією ідей, які згодом будуть доповнені, розширені, проте не втрачають свого тісного зв'язку зі своїм первинним джерелом. Це стосується ще одного важливого моменту: наявних опозицій «людинатварина», «дикість-цивілізованість» тощо, через які і реалізовується центральна проблема.

«Виховання необхідне тільки для людини», «людина може стати людиною лише завдяки вихованню. Вона не більше того, що 3 неї робить виховання». Ці твердження Канта $\epsilon$ ключовими в його педагогічній системі, вони «цементують» інколи розрізнені положення в єдине ціле, завдяки чому є всі підстави стверджувати: перед нами цілісна філософська програма формування такої особистості, яка потрібна суспільству і передовсім сама собі.

Під поняттям «виховання» Кант розуміє: «догляд» (нагляд), «дисциплінування» (становлення поведінки, соціалізація) і навчання разом із «формуванням морального обличчя». Догляд потрібен малюку, дисциплінувати належить дошкільників, навчати і формувати моральне обличчя треба школярам - тобто, кожному своє!

Людину відрізняе від тварини відсутність готових інстинктів, необхідність «становлення», ій самій необхідно формувати свій розум, у неї немає інстинктів; і вона змушена працювати над своєю поведінкою. Такий процес, підкреслював Кант, є постійним, оскільки в цьому випадку людство формує те, що і $€$ «людською природою». 
Цілеспрямований, усвідомлений процес виховання є гарантією поступу на шляху удосконалення людства: «Усвідомлення того, що завдяки вихованню людська природа буде прогресувати і що їй можна надати такої форми, яка б відповідала ідеалу, захоплює і відкриває перед нами перспективу більш щасливого майбуття людства» [1].

Саме суспільство на чолі «з сильними світу цього» несе відповідальність за якісне виховання, вважає І. Кант, оскільки виховати правильно може лише вихована людина, і якщо цим займаються особи, що самі погано виховані, то чи вони можуть правильно виховувати? «Якби коли-небудь за наше виховання взялася істота вищого порядку, тоді ми дійсно побачили б, якою може стати людина», - підкреслює мислитель.

Роздуми Канта сфокусовані на визнанні необхідності створення теорії виховання - «прекрасного ідеалу», який якщо на даний час і не може бути зреалізованим уповні, то це не означає, що він є недосяжним взагалі чи неістинним: «Ідея виховання, яке розвиває всі природні задатки людини, безперечно, відповідає істині». Підтвердження правильності своїх думок Кант знаходить у царині природи, оскільки вважає, що людина - істота природна: якщо квіти толокнянки, вирощені iз одного кореня, $є$ одного кольору, то вирощені із насіння, мають різні барви. «Відповідно, - робить він висновок, природа заклала в рослину різноманітні зародки, і розвиток тих чи інших зародків - справа правильного посіву і вирощування. Це подібне до виховання дітей. У людині криється чимало різноманітних зародків, і це ми повинні забезпечити їх ріст, гармонійно розвививаючи природні можливості людини $з$ тим, щоб вона могла досягти свого призначення» [1].

Кант заперечує можливість досягнення однією особистістю ідеалу виховання як «кінцевого призначення людини», вважаючи, що в цьому випадку потрібна робота не кількох людей, а передовсім всього людського роду, бо виховання $є$ мистецтвом, яке повинно удосконалюватися через досвід багатьох поколінь. Кожне покоління, оволодіваючи знаннями попереднього, здатне здійснювати таке виховання, яке більшою мірою гармонійно і цілеспрямовано розвиває природні здібності людини і тим самим просуває людину до iii призначення. Виділяючи два види виховання - «механічне» (випадкове, ситуативне) і «раціональне» (цілеспрямоване, наукове), - Кант уважав, що останній є набагато важливішим, 
оскільки «виходить із правильних основоположень» і підводить дітей до свідомого осягнення їх.

У процесі викладання цієї дисципліни Кант потрохи віддалявся від основного тексту підручників, цьому сприяли напружена філософська діяльність, що увінчалася публікацією праці «Критика чистого розуму» (1781), яка, за словами Б. Бім-Бада, створена 3 наміром навчити людей у їх дорозі до істини, без якої немає ні влаштування достойного суспільства, і достойної Людини долі окремої особистості, і включає окремий педагогічний розділ - вчення про метод, про дисципліну розуму, про його культуру [1].

Університетська освіта, як уважав Кант, має давати не лише знання, але й навчати студентів самостійно мислити, тому полюбляв говорити, що навчає не філософії, а філософствуванню, і завжди був супротивником зубріння і механічного запам'ятовування.

Як свідчать сучасники, він не любив, коли кожне його слово занотовували: це заважало вільному польотові думки. Читаючи лекції, передовсім Кант дбав, аби виклад навчального матеріалу був чітким, логічним і послідовним, а, головне, зрозумілим. Для цього дотримувався раз і назавжди виробленої методики. Перед початком лекції обирав когось із слухачів i, спостерігаючи за ним, робив висновки стосовно глибини розуміння усієї аудиторії: за необхідності повертався до особливо складних питань і розпочинав пояснення знову.

У роботі Кант орієнтувався на середнього студента: «Я читаю не для геніїв: вони самі собі прокладуть дорогу, але $\mathrm{i}$ не для дурнів; заради них не варто старатися, а для тих, хто знаходиться посередині і хоче підготувати себе до майбутньої роботи» [2, с. 90].

Матеріалом для лекцій слугували власні нотатки або підручники інших авторів, сторінки яких були яскравим свідченням копіткої роботи Канта: чисті поля були заповнені дрібним, проте розбірливим почерком філософа, помітками, що розвивали думки авторів, або, навпаки, заперечували $\mathrm{i}$ були вихідною позицією для еволюції самостійної думки. Збереглися свідчення одного із сучасників, які дають змогу відтворити загальну атмосферу, яка панувала на лекціях: «Його дотепність відрізнялася легкістю, винахідливістю, глибиною думки. Це були блискавки серед білого дня, він приправляв ними не тільки звичайну мову, але і лекції. Доте- 
пами він надавав доступної форми глибокодумності, повертаючи своїх втомлених слухачів із захмарних висот спекуляції на звичну землю» [2, с. 90].

На користь об'єктивності таких свідчень слугують спогади ще одного видатного німецького мислителя Й. Гердера, який навчався в Кенігсберзькому університеті і мав змогу упродовж трьох років слухати усі курси, які тоді читав Кант: «Його лекції мали характер приємної бесіди: він говорив про якого-небудь автора, але думав за нього сам <...> Я чув його оцінки Лейбніца, Ньютона, Вольфа, Крузія, Баумгартена, Гельвеція, Г'юма, Руссо, деякі із них були тоді новими письменниками, і треба зазначити, що єдиною метою при згадці цих імен було пробудити порив до істини, природний ентузіазм до блага людства, прагнення наслідувати велике і добре $<\ldots>$ Його філософія пробуджувала самостійну думку, і я не можу собі уявити більш дієвого засобу для цього, ніж його лекції; його думки ніби народжувалися на ваших очах, і треба було їх розвивати далі» [2, с. 59-60].

На початку 1790-х рр. у зв'язку з погіршенням здоров'я Кант все рідше з'являвся в аудиторії. Останню лекцію з дисципліни «Логіка» він прочитав 23 липня 1796 р., і хоч згодом ще тричі оголошував лекційні курси, але стан здоров'я став на заваді, тому заняття відмінялися. Проте активна наукова робота продовжувалася, і не тільки в руслі звичних філософствувань, але і в галузі педагогіки: свідченням цього є уже згадуваний трактат «Про педагогіку». Текст хоч і не зберіг ознак пізнішої редакції, проте серед використаної літератури вказані видання 1801-1802 pp.

Іммануїл Кант - визначна постать у світовому культурному процесі, мислитель, чиї ідеї сформувалися в часи XVIII го - «педагогічного століття» (як назвав його популярний тоді письменник І. Шуммель) під впливом неогуманістів, філантропіністів, які ставили за мету - розвиток усіх сил $\mathrm{i}$ здібностей людини, виховання любові до світу і до людей. Його значення для подальшого розвитку європейської $\mathrm{i}$ світової культури не випадково порівнюють із «революцією» Коперника, оскільки знаменитий мислитель із Кенігсберга повернув філософію з метафізичних просторів, визнавши для неї основним важливим об'єктом - людину.

Як переконливо доводить аналіз наукових джерел, саме тому важливою складовою наукової діяльності Канта була педагогічна діяльність, якій він присвятив майже 50 років, 
домагаючись не лише особистого і фахового зростання, але постійного розвитку та удосконалення суб'єктів навчального процесу.

Отже, головні завдання виховання, визначені Кантом, культивування особистості (навчання), цивілізування (соціалізація) і моралізування (моральне виховання) 3'явилися не лише в результаті теоретичних роздумів, а були результатом практичної діяльності, знайшовши своє відображення і в усій антропологічній системі мислителя, і в трактаті «Про педагогіку», зокрема.

Тому є всі підстави для ствердження необхідності глибокого i всебічного вивчення етико-педагогічної системи I. Канта в контексті сучасних проблем вітчизняної освіти, яка здатна не лише суттєво збагатити теоретичну базу гуманістичної освіти, але і сприятиме стабілізації суспільних відносин, нормалізації міжособистісних стосунків, оскільки вона зорієнтована на виховання доброчесної особистості, спроможної до етичних рефлексій на основі засвоєних i прийнятих моральних понять.

\section{Література}

1. Бим-Бад Б. М. Лекции Иммануила Канта «О педагогике» [Електронний ресурс] / Б. М. Бим-Бад. - Режим доступа: http://www.bim-bad.ru/biblioteka/article_full.php?aid=1806\&binn_rubri k_pl_articles=155. 2. Гулыга А. В. Кант / А. В. Гулыга. - М. : Молодая гвардия, 1977. - 304 с. - (Жизнь замечат. людей. Серия биографий. Вып. 7 (570)). 3. Дутчак В. В. Рефлексія метафізики держави I. Канта (історико-філософський аспект): автореф. дис. на здобуття наук. ступеня канд. філософ. наук: спец. 09.00.05 «Історія філософії» / В. В. Дутчак. - Дніпропетровськ, 2005. - 20 с. 4. История философии в кратком изложении / [пер. с чеш. И. И. Богута]. - М. : Мысль, 1991. - 590, [1] с. (Библ. серия). 5. Кант И. Антропология з прагматической точки зрения // Собрание сочинений : в 6 т. / Иммануил Кант. - М. : Мысль, 1963 - 1966. - Т. 6. - 1966. - С. 349 - 588. 6. Кругликова Г. Г. Проблема человека в философии Иммануила Канта и философско-педагогических концепциях русских мыслителей второй половины XIX - первой трети XX века : автореф. дис. на соискание уч. степени канд. философ. наук: спец. 09.00.03 «История философии» / Г. Г. Кругликова. - Нижневартовск, 2002. - 19 с. 7. Луговой С. В. Интерпретация Библии в практической философии И. Канта : автореф. дис. на соискание уч. степени канд. философ. наук: спец. 09.00.03 «История философии» / С. В. Луговой. - Калининград, $2007 . \quad-20$ с. 8. Новичкова Г. А. Историко-философские очерки западной педагогической антропологии [Електронний ресурс] 
Г. А. Новичкова. - М. : ИФ РАН, 2001. - 142 с. - Режим доступа: http://pedlib.ru/Books/5/0261/5_0261-1.shtml. 9. Павлова Т. С. Співвідношення моралі i права у філософії І. Канта (історикофілософський аналіз) : автореф. дис. на здобуття наук. ступеня канд. філософ. наук: спец. 09.00 .05 «Історія філософії» / Т. С. Павлова. - Дніпропетровськ, 2007. - 18 с. 10. Смігунова О. Г. Естетика I. Канта: продуктивна уява і принцип доцільності : автореф. дис. на здобуття наук. ступеня канд. філософ. наук: спец. 09.00.08 «Естетика» / О. Г. Смігунова. - К., 2007. - 18 с.

\section{ЄВРОПЕЙСЬКІ ТЕНДЕНЦЇ̈ В РОЗВИТКУ ОСВІТИ ДОРОСЛИХ}

\footnotetext{
У статті охарактеризовано міжнародні тендениії розвитку освіти дорослих на категоріальному, практичному, історико-педагогічному рівнях. Розкрито роль освіти дорослих у забезпеченні позитивних змін суспільного життя; наголошено на важливості проведення порівняльних досліджень у галузі освіти дорослих.

Ключові слова: порівняльні дослідження у сфері освіти дорослих, зміст освіти дорослих, специфіка освіти дорослих.
}

В статье охарактеризованы международные тенденции развития образования взрослых на категориальном, практическом, историко-педагогическом уровне. Раскрыта роль образования взросльх в обеспечении позитивных изменений общественной жизни; подчеркивается важность проведения сравнительных исследований в области образования взрослых.

Ключевые слова: сравнительные исследования в сфере образования взросльх, содержание образования взросльх, специфика образования взрослых.

The article describes some international trends at adult education development on the level of category, practice, history and comparative-education. The role of adult education in development of positive trends in social life is highlighted at the article either, main attention here is attracted to the importance of comparative research in the field of adult education.

Key words: comparative investigations in the adult education area, content of adult education, specific of the adult education.

Протягом останніх років спостерігається кількісне зростання контингенту тих, хто навчається у системах післядипломної освіти, підвищення кваліфікації, перекваліфікації. Саме тому виникає необхідність дослідження проблематики освіти дорослих, яка безпосередньо пов'язана із цією сферою.

Початок XXI століття характеризується перетворенням освіти дорослих у потужний чинник суспільного прогресу $\mathrm{i}$ 